\title{
PERUBAHAN-PERUBAHAN ORGANISASIONAL DALAM DINAS PERTANIAN TANAMAN PANGAN DAN PETERNAKAN KABUPATEN NUNUKAN SETELAH BERLAKUNYA U.U. PEMERINTAHAN DAERAH NO. 32/2004
}

\author{
Samodra Wibawa \\ FISIPOL Universitas Gajah Mada \\ Sosio Yustisia Bulaksumur, Yogyakarta 55281 \\ Email:samodra03@yahoo.com
}

\begin{abstract}
This paper describes and analyses changes that occurred in the Department of Plantation and Livestock (Dinas Pertanian Tanaman Pangan dan Peternakan, Dispertanak) Kabupaten Nunukan. There are some 19 aspects that were examined, consisted of 30 items. Among these items, there were 13 (42\%) items which experienced positive changes, such as office equipment, formal and informal communication, quality employees, and program evaluation. A total of 5 (16\%) items regent; and $12(39 \%)$ items remained relatively unchanged, for example the flow at tasks, project orientation, and decision making process. This condition is not so encouraging. Dispertanak needs to do introspection, then makes up his mind to make positive change significantly and innovatively through a process of learning organisation.
\end{abstract}

Keywords : organizational change, nepotism, innovation, decision making, learning organisation.

\begin{abstract}
Abstrak
Tulisan ini mendeskripsikan dan menganalisis perubahan-perubahan yang terjadi di Dinas Pertanian Tanaman Pangan dan Peternakan Kabupaten Nunukan. Ada 19 aspek yang dikaji, terdiri dari 30 butir kajian. Di antara butir-butir ini terdapat $13(42 \%)$ butir yang mengalami perubahan positif, misalnya peralatan kantor, komunikasi formal dan informal, kualitas pegawai dan evaluasi. sebanyak $5(16 \%)$ butir relatif tidak berubah, misalnya aliran tugas, orientasi proyek dan proses pembuatan keputusan. Kondisi ini kurang begitu menggembirakan. Dispertanak perlu melakukan mawas diri, untuk kemudian membulatkan tekad melakukan perubahan-perubahan positif yang lebih signifikan dan inovatif melalui proses learning organisation.
\end{abstract}

Kata kunci: Perubahan organisasi, nepotisme, inovasi, pengambilan keputusan, learning organisation.

${ }^{1}$ Naskah diterima: 5 Juni 2012, revisi pertama: 16 Juli 2012, revisi kedua: 26 Juli 2012, revisi terakhir: 28 Juli 2012 


\section{PENGANTAR}

Perubahan di dalam suatu organisasi adalah sebuah keniscayaan. Berbagai dimensi atau aspek di dalam organisasi tidak bisa tidak harus berubah seiring dengan perkembangan jaman: menjadi lebih canggihnya teknologi, sistem politik yang semakin demokratis dan transparan, perdagangan antar daerah dan antar negara yang semakin intensif, kondisi sosial dan budaya masyarakat yang bergerak maju, dan seterusnya.

Dinas Pertanian Tanaman Pangan dan Peternakan (Dispertanak, selanjutnya dalam tulisan ini akan sering disebut Dinas) Kabupaten Nunukan, Kalimantan Utara, juga tidak terlepas dari keharusan tersebut. Dia harus merespon perubahan lingkungannya, untuk dapat melayani secara lebih baik dan mencapai tujuan serta misinya secara lebih efektif, efisien dan adil.

Tulisan ini akan mendeskripsikan perubahan-perubahan yang telah terjadi di dalam Dinas, yakni setelah tahun 2005. Tahun ini dipilih sebagai titik pemisah perbandingan, karena pada tahun ini mulai berlaku UU Pemerintahan Daerah yang baru (No. 32/2004), yang merevisi UU No. $22 / 1999$.

\section{METODE PENELITIAN}

Deskripsi dalam tulisan ini didasarkan pada informasi yang diperoleh dari enam orang informan, semuanya adalah pegawai Dinas, baik pejabat struktural maupun staf. Mereka diminta menuliskan apa saja kondisi yang berbeda di dalam Dinas antara sebelum dan setelah 2005. (Jadi unit analisisnya adalah organisasi.) Informasi mereka disajikan secara tertulis, dan artikel ini merangkum serta mengomentarinya. Ada satu-dua informasi yang tidak sama atau berentangan dari keempatnya, dan penulis memilahnya secara judgmental. Penilaian penulis ini dilakukan setelah melakukan interview lisan maupun tertulis via email.

Tulisan ini tidak bersifat analitik, dalam arti menunjukkan mengapa sesuatu hal terjadi dan apa akibatnya, melainkan lebih bersifat deskriptif. Namun penulis memberikan penafsiran dan komentar terhadap data yang diperoleh dari informan, yang ini pada kadar tertentu adalah sebuah aktivitas analitik. Diharapkan tulisan ini bermanfaat memberikan gambaran yang relatif menyeluruh kepada para ilmuwan Administrasi Negara, aspekaspek apa saja yang telah berubah di suatu instansi pemerintah di Indonesia. Tulisan ini ditutup dengan usulan daftar agenda penelitian tentang organisasi pemerintah, khususnya pemerintah kabupaten.

\section{KONSEP PERUBAHAN ORGANISASI}

Perubahan adalah keniscayaan, baik karena dorongan dari luar maupun dari dalam organisasi sendiri.

Pendorong itu antara lain perubahan sistem ekonomi dunia dan perkembangan teknologi, yang kemudian berpengaruh terhadap perilaku manusia dan budaya organisasi pada umumnya (bandingkan dengan Andari 2005). Organisasi perlu diubah dari waktu ke waktu untuk meningkatkan profesionalisme dan integritas pegawai agar mampu memberikan pelayanan yang prima kepada masyarakat. Cara kerjanya adalah bahwa perubahan organisasi 
diarahkan pada terbentuknya budaya yang baru yang lebih kondusif sehingga para pegawai mengalami kepuasan kerja yang tinggi, sehingga kinerja mereka meningkat (lihat Prawirodirdjo 2007). Robbins (2003) menyebutkan, bahwa pada dasarnya semua perubahan diarahkan pada peningkatan efektiftas organisasi dengan memperbaiki kemampuan organisasi dalam menyesuaikan diri terhadap perubahan lingkungan serta perubahan perilaku anggota organisasi. (Bandingkan pula dengan Kahar 2008; tentang emosi dalam perubahan organisasi dibahas oleh Yuwono/Putra 2005.)
Perubahan organisasi mencakup banyak aspek. Prawirodirdjo (2007: 815) menyebutkan empat aspek: struktur, teknologi, prosedur dan manajemen pegawai. Andersen (dikutip Elu dan Purwanto 2011:1.3032) mendaftar banyak aspek organisasional yang terlibat dalam perubahan seperti terlihat pada Gambar 1. Dari beberapa literatur yang dikaji dalam penyiapan artikel ini, khususnya Elu dan Purwanto (2011), dapat didaftar 19 aspek dari suatu organisasi, mulai dari peralatan kantor, motivasi kerja, proses perencanaan hingga proses inovasi. Kesemuanya akan diuraikan satu per satu, bagaimana kondisinya di dalam Dispertanak.

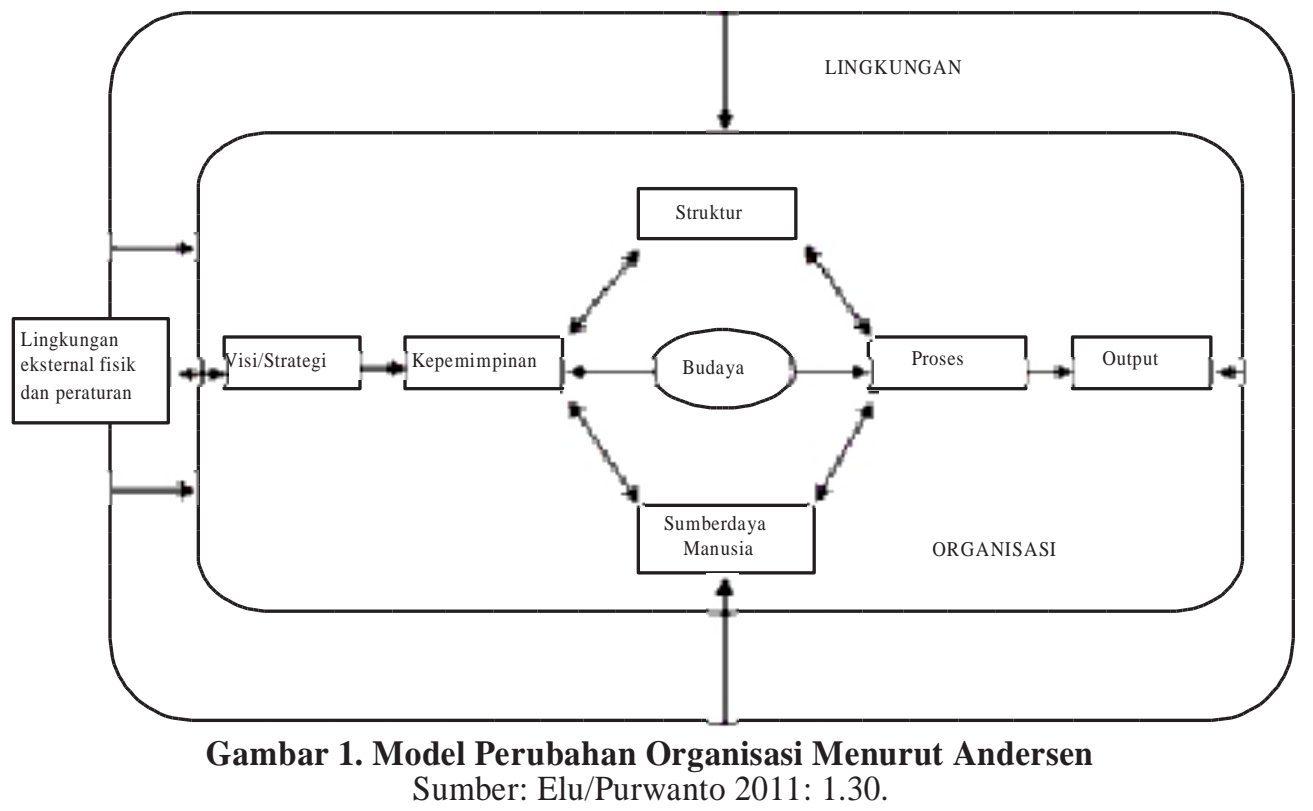

\section{PERUBAHAN-PERUBAHAN DI DALAM DINAS : 19 ASPEK}

Dinas Pertanian Tanaman Pangan dan Peternakan Kabupaten Nunukan dibentuk pada tahun 2001 melalui Peraturan Kabupaten Nunukan tentang Pembentukan Organisasi
Dinas-Dinas Daerah kabupaten Nunukan (Perda No. 03/2001), kemudian diperbaharui melalui Peraturan Kabupaten Nunukan tentang Pembentukan, Susunan Organisasi dan Tata Kerja Dinas-Dinas (Perda No. 23/2008). Berikut ini berbagai 
perubahan yang terjadi di dalam instansi ini antara sebelum dan setelah tahun 2005.

\section{Peralatan Kantor}

Sebelum tahun 2005 peralatan kantor masih sangat minim dan terbatas. Lagi pula kantor yang digunakan masih kontrak dan ruangannya masih sangat sempit. Peralatan kantor yang ada adalah meja, kursi, mesin ketik, lemari arsip, ATK seperti buku, pulpen, pensil, rautan pensil, penggaris, staples, kertas, papan data, pengeras suara, map, map gobi, amplop, telpon, mesin fax. Pada saat itu komputer sudah ada meski masih sederhana dengan program lotus dan layar besar serta kemampuannya hanya Pentium 1 dan 2. Laptop masih langka dan mahal. Penyimpanan data menggunakan disket dan CD. Printer umumnya masih menggunakan pita, dan sebagian aktivitas surat menyurat masih menggunakan mesin ketik.

Setelah 2005 kantor baru relatif agak luas, meski status masih tetap kontrak, dan pada akhir 2009 Dinas menempati kantor baru, di mana setiap pejabat eselon II sudah memiliki ruangan tersendiri. Komputer sudah makin canggih dengan program XP dan lainnya dengan layar datar LCD serta kemampuan sampai Pentium 5, laptop sudah bukan barang langka dan hampir semua pegawai memiliki laptop pribadi. Tersedia pula layar presentasi dengan LCD yang canggih. Printer yang ada juga semakin canggih dan dapat digunakan untuk fotokopi. Untuk menyimpan data sudah menggunakan flashdisk aneka bentuk sampai ukuran yang sangat kecil.

Dalam aspek pertama ini terjadi perubahan yang sangat luar biasa, dikarenakan kemajuan teknologi. Mestinya ini meningkatkan kemampuan organisasi untuk mengolah data, merencanakan program dan melakukan komunikasi serta koordinasi intern Dinas maupun dengan instansi lain, di dalam maupun di luar Nunukan. Tapi ternyata, seperti akan ditunjukkan di bawah, kemajuan peralatan tidak memperbaiki hal-hal yang baru saja disebu secara signifikan.

\section{Struktur Organisasi}

a. Bagan organisasi. Sebelum tahun 2005 urusan organisasi sangat banyak, karena Dinas masih membawahi perikanan, kehutanan, peternakan, perkebunan, ketahanan pangan dan penyuluhan. Setelah tahun 2005 urusan organisasi lebih sedikit, karena urusan perikanan, kehutanan dan perkebunan ditangani dinas tersendiri. Pada tahun 2008 dibentuk pula Badan Ketahanan Pangan dan Penyuluhan, sehingga urusan Dinas menjadi semakin sedikit: tinggal mengurusi pertanian tanaman pangan dan peternakan saja. Namun jauh berkurangnya tugas Dinas tidak menjadikan struktur juga jauh lebih ramping. Jika sebelum 2005 jumlah seksinya 18 buah, sekarang hanya berkurang sedikit menjadi 13 seksi/subbag. Ini kiranya bukan perampingan yang signifikan. 
Ini kiranya suatu keanehan, dan menjadikan para pegawai banyak menganggur sehari-

harinya.

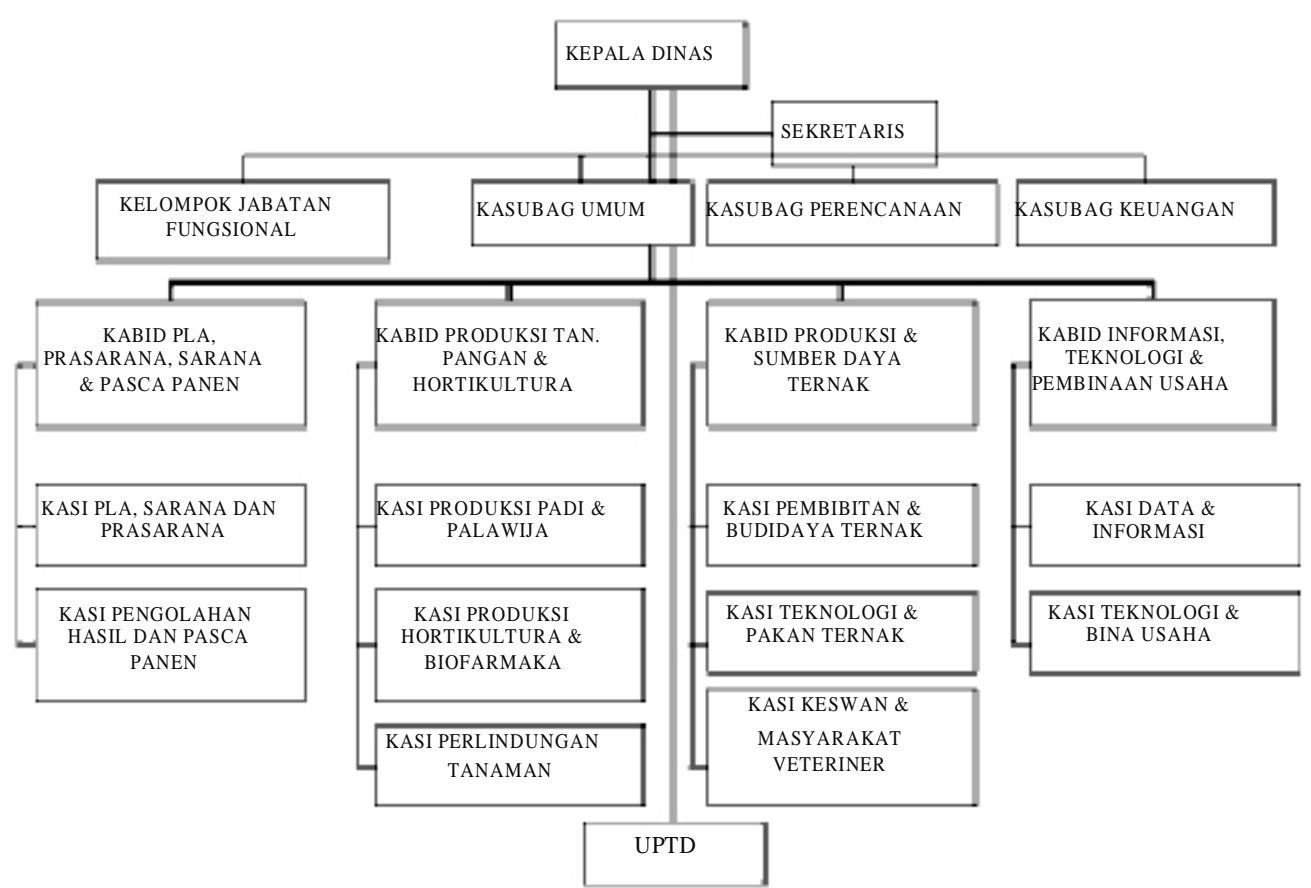

Gambar 2. Struktur Organisasi Dispertanak Nunukan Tahun 2011

b. Jumlah pegawai. Sementara itu jumlah pegawai malah meningkat, dari 42 orang sebelum tahun 2005 menjadi 88 orang sesudahnya! (Lebih dari dua kali lipat, termasuk tenaga honorer tapi tidak termasuk petugas penyuluh lapangan.) Saat ini jumlah pegawai menjadi 101 orang, 64 orang di antaranya honorer (lihat Tabel 1). Ini adalah juga keanehan: urusan berkurang banyak, tapi pegawai malah bertambah. Lebih dari itu perbandingan antara PNS dan pegawai honorer, di mana yang honorer berjumlah lebih banyak daripada PNS adalah juga suatu kejanggalan. Mestinya jumlah pegawai honorer itu sedikit, sekedar menambal kekurangan tenaga. Patut dicurigai, bahwa birokrasi dijadikan sebagai tempat mencari penghasilan, bukan terutama diorientasikan untuk pelayanan masyarakat secara efisien dan adil.

Hanya saja, menurut informan, memang tenaga honorer diperlukan keberadaannya. Sekalipun jumlah urusan berkurang, tetap saja pekerjaan sehari-hari banyak. Jumlah pegawai yang ada tidak mencukupi. Kalau tidak ada tenaga honorer, para pejabat eselon IV akan kewalahan dalam mengelola tugas pokok dan fungsi mereka, terutama dalam membukukan 
kegiatan maupun melaporkan

kegiatannya. Namun cara rekruitmen atas tenaga honorer ini belumlah ideal. Ada yang melalui nota Bupati atau anggota DPRD, ada yang titipan dari pejabat Eselon IIa dan IIb, ada pula yang melalui pejabat eselon III atau IV. Jadi hubungan keluarga atau pertemanan sangatlah kental. Sehingga kalau pemerintah pusat sekali-sekali mem-PNS-kan mereka secara otomatis sebenarnya tidaklah tepat. Mestinya tenaga honorer tidak perlu diberi prioritas dalam penerimaan PNS, karena cara mereka direkruit tidak berdasarkan merit system.

Tabel 1. Kondisi Pegawai di Dispertanak Kabupaten Nunukan Tahun 2011

\begin{tabular}{|c|c|c|c|c|c|c|c|c|c|c|c|c|}
\hline \multirow{2}{*}{ No } & \multirow{2}{*}{\begin{tabular}{c}
\multicolumn{2}{c}{ Klasifikasi } \\
Struktural
\end{tabular}} & \multicolumn{3}{|c|}{ PNS Golongan } & \multirow{2}{*}{$\begin{array}{l}\text { Non } \\
\text { PNS }\end{array}$} & \multirow{2}{*}{ Jml } & \multicolumn{5}{|c|}{ Tingkat Pendidikan } & \multirow{2}{*}{$\begin{array}{l}\mathrm{Jml} \\
\mathrm{J} \mathrm{mI}\end{array}$} \\
\hline & & II & III & IV & & & SLTP & SLTA & D3 & S1 & S2 & \\
\hline & - Eselon II & & & 1 & & 1 & & & & & 1 & 1 \\
\hline & - Eselon III & & 4 & 1 & & 4 & & & & 4 & 1 & 4 \\
\hline & - Eselon IV & & 13 & & & 13 & & & & 13 & & 13 \\
\hline & & & & & & & & & & & & \\
\hline & Non Jabatan & & 2 & & & 20 & 2 & 12 & 4 & 2 & & 20 \\
\hline & & & & & & & & & & & & \\
\hline & Honorer & & & & & & & & & & & \\
\hline & - TKK & & & & 1 & 1 & & & & 1 & & 1 \\
\hline & - Tenaga Bantu & & & & 61 & 61 & & 39 & 4 & 17 & & 61 \\
\hline & - THL POPT & & & & 2 & 2 & & 1 & & 1 & & 2 \\
\hline & nlah & 15 & 19 & 2 & 64 & 101 & 2 & 52 & 8 & 38 & 2 & 101 \\
\hline
\end{tabular}

Keterangan:

- TKK: Tenaga kontrak kabupaten

- THL PPOT: Tenaga Harian Lepas Pengamat Organisme Pengganggu Tanaman

c. Aliran Tugas. Bagaimana tugas mengalir dari atas ke bawah kiranya tidak mengalami perubahan antara sebelum dan sesudah 2005. Aliran tugas mengikuti hierarkhi dan fungsi, dimana kepala dinas melimpahkan sebagian kewenangannya kepada sekretaris dan kepala bidang, demikian pula dengan sekretaris dan kepala bidang yang melimpahkan sebagian kewenangannya kepada kasubbag dan kepala seksi. Selanjutnya kepala seksi memberikan perintah kepada staff. Aliran yang sebaliknya berlangsung dalam hal saran, yakni dimulai dari bawah berlanjut ke atas secara hierarkis dan tidak boleh melangkahi atasan langsung.

Ta m pa kn y at id a k terelakkan, bahwa jalur komando dari atas ke bawah haruslah diikuti, karena hal ini berimplikasi pada persoalan hukum. "Demokrasi administrasi" atau "administrasi partisipatif" yang tampaknya disarankan oleh beberapa pihak dalam beberapa tahun terakhir (lihat misalnya Dujo, tt.), di mana semua anggota Dinas membuat keputusan bersama- 
sama dan melaksanakannya sesuai spesialisasi masingmasing, kiranya masih merupakan barang mewah dan langka. Hierarkhi dan komando kiranya masih kental mewarnai birokrasi kita. Tapi ini memang dapat dipahami, karena menyangkut pada struktur pertanggungjawaban: apa saja yang dikerjakan oleh bawahan haruslah hal yang tidak saja diketahui melainkan diijinkan dan diperintahkan oleh atasan.

\section{d. Komunikasi formal. Sama}

seperti aliran tugas, komunikasi formal juga tidak mengalami perubahan. Namun saat ini lebih sering dilakukan karena sudah tersedianya ruangan yang cukup baik untuk melakukan rapatrapat, baik rapat dinas, rapat staf, rapat terbatas, rapat bidang dan rapat seksi. Komunikasi formal dilakukan dengan bahasa Indonesia baku secara baik dan benar, baik secara tertulis maupun lisan. Etiket dan kesopanan berkomunikasi juga sangat terjaga.

\section{Komunikasi Informal}

Sebelum tahun 2005

komunikasi informal dilakukan dengan tatap-muka langsung ataupun telpon. Kini komunikasi informal lebih dominan menggunakan HP atau internet.

Bahasa yang dipakai adalah bahasa Indonesia, tapi banyak yang berdialek Kalimantan dengan pengaruh Malaysia. Komunikasi informal diperlukan untuk memperpendek jalur birokrasi, untuk mengkomunikasikan hal-hal yang harus lebih cepat tertangani, dan untuk hal-hal yang bersifat rahasia atau privacy. Misalnya mengundang rapat yang mendadak, memanggil staf, untuk menanyakan keberadaan staf lapangan saat ini, untuk pesan persiapan bahan rapat dari kepala dinas dan seterusnya ke bawah dll.

Melalui komunikasi informal terjadi hubungan antar-manusia. Di sini orang membicarakan masalah ekonomi, politik, sosial sampai acara radio, atau acara musik, film dan sinetron TV, dunia olah raga. Juga dibicarakan masalah keluarga dan anak-anak. Ini semua dapat menambah pengetahuan dan pengalaman dan kemudian dapat mengubah cara pandang, sikap dan perilaku pegawai.

Seorang informan menyebutkan manfaat komunikasi informasl sebagai berikut:

a. Menghubungkan semua unsur yang melakukan interrelasi pada semua lapisan, sehingga menimbulkan rasa bersatu, kesetiakawanan dan loyalitas.

b. S e mu a jajaran pi mpin an mengetahui langsung bidangbidang yang dibawahi, sehingga dapat mengendalikan keseluruhan sistem.

c. Meningkatkan rasa tanggung jawab semua anggota, menumbuhkan rasa terlibat pada kepentingan organisasi.

d. Memunculkan saling pengertian dan saling menghargai tugas masing-masing sehingga menimbulkan rasa persatuan dan pemantapan semangat kelompok.

e. Terwujudnya iklim kerja yang 
lebih baik meliputi, kesatuan dan persatuan, kepuasan kerja dan juga menambah gairah kerja.

\section{Budaya Organisasi}

Sebelum tahun 2005 budaya organisasi masih lebih terbuka sehingga semua pegawai/staf merasa diperlakukan sama dan keakraban masih terasa karena belum adanya sekat antar bidang. Setelah tahun 2005 budaya organisasi lebih tertutup karena staf hanya merasa menjadi bagian dari bidang dan setiap bidang sibuk dengan kegiatan masing-masing. Kiranya ini merupakan sebuah anomali: teknologi komunikasi semakin canggih, tetapi orang semakin tertutup satu sama lain. Rasa keakraban menurun. Apakah ini gejala individualismematerialistik yang semakin kuat di dalam tubuh birokrasi?

Sementara itu, dalam kaitannya dengan karir, kedekatan seorang pegawai dengan bupati masih sangat menentukan.

Kebijakan puncak dari Bupati menjadi keputusan mutlak yang kadang harus diikuti. Nepotisme dalam hal penerimaan tenaga honorer kerap terjadi.

Penghormatan berdasarkan hierarki struktural sangat berlaku. Bawahan harus patuh pada atasannya. Campur tangan istri pejabat dalam kebijakan kantor kadang terjadi. Seseorang yang pernah membuat kesalahan kadang-kadang dikucilkan, sementara mereka yang berprestasi mendapat perhatian yang baik. Kiranya ini merupakan pemandangan yang manusiawi: nepotisme; namun sudah diimbangi dengan penghargaan kepada prestasi. Diharapkan sisi yang kedua ini semakin kuat dan sisi nepotisme semakin menyurut. Namun hukuman berupa pengucilan perlu dikurangi. Pihak terhukum haruslah diberitahu apa kesalahannya dan diberi kesempatan untuk melakukan pembelaan; bukannya dikucilkan begitu saja tanpa pemberitahuan dan pembinaan yang semestinya.

\section{Kualitas dan Motivasi Kerja Pegawai}

Sebelum tahun 2005, jumlah dan mutu pegawai masih sangat terbatas, karena Kabupaten Nunukan baru saja didirikan. Beban kerja sangat tinggi dan belum tersedia sarana dan prasarana yang memadai. Tapi justru karena itu motivasi kerja sangat tinggi. Sebagian besar pegawai adalah lulusan perguruan tinggi dari Jawa, Sulawesi dan Samarinda. Motivasi kerja tinggi, karena rata-rata mereka sadar akan persaingan hidup dalam perantauan, di samping adanya tambahan tunjangan kemahalan daerah perbatasan.

Setelah tahun 2005 kualitas pegawai mengalami peningkatan karena rekruitmen CPNS diprioritaskan tingkat pendidikan S1, khususnya untuk mengisi kekosongan jabatan di Dinas. Dengan bertambahnya jumlah pegawai maka beban kerja sudah mulai berkurang. Tambahan tunjangan kemahalan daerah perbatasan tetap menjadi pendorong motivasi yang tinggi bagi pegawai. Pelatihan kerja juga meningkatkan kualitas pegawai. Namun demikian, 
patut dicatat pula bahwa terkesan motivasi pegawai sedikit menurun dibanding masa sebelum 2005. Beban kerja yang sedikit menjadikan pegawai terpaku pada spesialisasinya masing-masing, dan tidak jarang mereka menganggur. Kiranya ini adalah pelajaran yang sangat berharga: justru ketika pekerjaan sangat sedikit, semangat kerja malah melemah. Pembagian dan pembebanan kerja memang pada praktiknya adalah sebuah seni: pegawai harus dibebani pekerjaan yang "pas" -tidak terlalu banyak, tapi juga tidak terlalu sedikit; dan ini berbeda-beda antar individu.

\section{Anggaran Dinas}

Dalam melaksanakan tugas dan fungsinya, Dispertanak didukung oleh anggaran yang berasal dari Pemkab Nunukan, Pemrpov Kaltim maupun

Kementerian Pertanian. Sebelum tahun 2005 anggaran Dinas masih sangat minim karena Pemkab lebih fokus pada pembangunan fisik, puncaknya pada tahun 2005 Dinas tidak mendapatkan anggaran untuk pelaksanaan kegiatan, kecuali untuk anggaran rutin, sehingga kegiatan yang dilaksanakan adalah kegiatan yang berasal dari Pemprov, DAK dan APBN.

Setelah tahun 2005 Pemkab mulai memberikan porsi anggaran yang cukup signifikan. Adapun perkembangan anggaran Dispertanak sejak tahun 2006 2011 terlihat dalam Tabel 2.
Tabel 2. Jumlah Anggaran Dipertanak Tahun 2006-2011

\begin{tabular}{|c|c|}
\hline Tahun & Jumlah Anggaran (rupiah) \\
\hline 2006 & 14.210 .107 .185 \\
2007 & 12.417 .488 .525 \\
2008 & 13.054 .813 .920 \\
2009 & 17.905 .230 .615 \\
2010 & 9.188 .330 .022 \\
2011 & 17.264 .521 .054 \\
\hline
\end{tabular}

Anggaran Dispertanak tidak linear tiap tahun, tetapi sangat dipengaruhi oleh prioritas dan program Pemerintah Kabupaten, Dinas Pertanian Tanaman Pangan Provinsi Kalimantan Timur, Dinas Peternakan Kalimantan Timur dan Kementerian Pertanian. Di sini perlu diberi catatan, yaitu bahwa alokasi anggaran tidak didasarkan pada program atau tujuan yang jelas, melainkan lebih didasarkan pada pembagian kegiatan.

"Orientasi proyek" seperti ini kiranya tidak kunjung terkikis dari birokrasi kita. Mestinya perlu ada kelompok-kelompok masyarakat yang mulai melakukan pengawasan terhadap anggaran pemerintah, sehingga dana "negara" (pada hakekatnya adalah uang rakyat) tidak hanya dibagi-habis di kalangan birokrat (dan politisi) melainkan untuk menghasilkan capaian-capaian yang bermanfaatnyata bagi masyarakat.

Kesan bahwa anggaran kabupaten tidak sedikit yang sebenarnya hanya untuk dibagi-bagi di kalangan stakeholders di kabupaten dikuatkan dengan peristiwa tahun 2010. Pada tahun ini jumlah anggaran hanya Rp. 9 
milyar, jauh lebih sedikit dibanding tahun-tahun sebelum dan sesudahnya (lihat Tabel 2). Menurut seorang informan, hal ini terjadi karena pada tahun tersebut dana alokasi umum dari pusat untuk seluruh kabupaten/kota di Kalimantan Timur dikurangi hampir 50\%. Salah satu alasannya adalah, bahwa pada tahun 2011 akan berlangsung pilkada di banyak kabupaten/kota, dan dicurigai bahwa dana akan disedot oleh golongan atau kelompok tertentu untuk memenangkan pilkada tersebut. Namun menurut informan lain, anggaran tahun 2010 menurun drastis dikarenakan Pemkab harus melunasi utang pada pembangunan fisik periode sebelumnya.

\section{Dukungan Bupati}

Dukungan dari bupati yang

paling jelas adalah anggaran sebagaimana diuraikan di atas. Bupati periode 2001 sampai 2011 memberikan dukungan yang kecil saja. Meskipun sektor pertanian dinyatakan sebagai prioritas pembangunan di Kabupaten Nunukan, anggaran yang diterimanya hanya berkisar $1 \%$ dari APBD Kabupaten Nunukan. Rupanya pembangunan infrastruktur masih jauh diprioritaskan. Lebih dari itu perkebunan sawit juga mendapat porsi perhatian yang lebih besar (ini bukan urusan Dispertanak melainkan Dinas Kehutanan dan Perkebunan). Saat ini sebagian anggaran Dispertanak ditopang oleh anggaran Pemprov Kaltim berupa bantuan keuangan dan Kementerian Pertanian berupa tugas pembantuan.

Sedangkan bupati baru (menjabat per Mei 2011) berjanji akan mengurangi porsi anggaran untuk pembangunan fisik dan menambah forsi anggaran untuk program pengentasan kemiskinan dan peningkatan kesejahteraan masyarakat, misalnya melalui sektor pertanian.

Penulis tidak bisa memberikan penilaian, apakah porsi anggaran sekitar Rp15M per tahun telah pantas untuk Kabupaten Nunukan, mengingat data yang kurang. Tetapi porsinya yang hanya $1 \%$ dari anggaran Kabupaten kiranya pastilah sangat tidak memadai, mengingat pertanian masih merupakan mata pencaharian penting penduduknya. PDRB sektor pertanian di Nunukan pada 2005 mencakup 21\% dari keseluruhan PDRB Kabupaten, dan pada 2009 meningkat menjadi 25\% (BPS Nunukan 2010)!

\section{Visi Organisasi}

Sebelum tahun 2005 visi

Dinas adalah "mewujudkan pertanian yang tangguh dalam mendukung kabupaten Nunukan menjadi kawasan perdagangan agroindustri dan jasa di kawasan Asia Tenggara dalam rangka menyongsong era perdagangan bebas yang didukung oleh SDM yang menguasai iptek dan dilandasi iman dan taqwa". Setelah tahun 2005 visinya dipersingkat menjadi "terwujudnya swasembada pangan dan daging di Kabupaten Nunukan tahun 2015".

Tapi sepertinya visi seperti itu hanyalah lip-service, pemanis di 
bibir, syarat pelengkap bagi eksistensi suatu dinas. Tidak pernah dilakukan evaluasi yang sistematis, apakah visi telah terealisir -untuk kemudian diubah, jika tidak realistis. Jika visi hanyalah formalitas, maka kegiatan Dinas pun hanyalah formalitas, tidak berorientasi kepada pencapaian tujuan tapi sekadar berkegiatan -pembagian anggaran.

\section{Kepemimpinan Kepala Dinas Kepala Dispertanak telah} berganti tiga kali sejak Dispertanak berdiri pada 2000, yakni pada tahun 2006, 2010 dan 2011. Sebelum tahun 2005, dalam mengambil keputusan Kepala Dinas lebih sering meminta masukan dari bawahan sehingga keputusan yang diambil dapat diterima dan dilaksanakan oleh staf, tetapi kurang tegas terhadap bawahan yang melakukan pelanggaran. Dia sangat bertanggungjawab secara moral maupun jabatan atas apa yang berlangsung di Dinas. Dapat dikatakan, bahwa dia sangat baik, patuh pada peraturan tetapi sekaligus fleksibel dan memperhatikan bawahan. Cenderung lebih berorientasi kepada manusia daripada kepada tugas.

Setelah tahun 2005, Kepala

Dinas lebih tegas dan mengedepankan etos kerja dan kedisiplinan dalam melaksanakan tugas. Mungkin dapat dikatakan, bahwa dia cenderung berorientasi ke tugas daripada manusia. Dapat dinilai bahwa dia "cukup baik", dapat memimpin dinas, tegas, patuh pada peraturan, menerima saran dari bawahan. Tapi sering muncul kesan bahwa Kepala Dinas cenderung "mengamankan" diri sendiri sehingga staf terkadang kurang motivasi dan loyal dalam bekerja.

Berdasar uraian para informan ini dapat ditafsirkan, bahwa dalam masa sulit (yakni di awal berdirinya Kabupaten Nunukan) rasa kebersamaan lebih tinggi daripada di masa lapang. Individualisme-egoisme lebih mengemuka pada masa lapang, termasuk pemimpin pun dilanda sikap ini. Dibarengi dengan menurunnya secara drastis jumlah pekerjaan Dinas, hal ini menjadikan semangat kerja para pegawai juga menurun tajam (lihat bagian "kualitas dan motivasi pegawai" di atas).

\section{Kepemimpinan Kepala Bidang}

Sebelum tahun 2005, karena keterbatasan jumlah pegawai, Kepala Bidang masih terlibat sebagai pelaksana kegiatan dan panitia pengadaan barang dan jasa sehingga fungsi kontrol terhadap Kepala Seksi dan staf masih belum maksimal. Sebaliknya dia relatif baik, memberikan pelajaran tentang cara bekerja, membimbing bawahan. Kepala Bidang bertanggungjawab atas semua yang terjadi pada bidangnya dan sering melakukan rapat secara berkala untuk mengetahui perkembangan bidangnya. Akan tetapi program dijalankan berdasarkan capaian prestasi besarnya anggaran, bukan pada manfaat program bagi masyarakat.

Setelah tahun 2005, Kepala 
Bidang tidak terlibat lagi sebagai pelaksana kegiatan dan panitia pengadaan barang dan jasa sehingga fungsi kontrol atau pengawasan terhadap Kepala Seksi dan staf lebih optimal. Sekalipun dapat dikatakan baik, ada kepala bidang yang terkesan kurang memperhatikan bawahannya, program dijalankan to the point pada hasil dan kadang kurang memperhatikan perjalanan prosesnya. Namun sepertinya Kepala Bidang sekedar ingin menikmati tunjangan dan fasilitas yang lebih tanpa ada rasa tanggungjawab terhadap pekerjaannya.

Komentar terhadap kepemimpinan Kepala Dinas tampaknya berlaku pula untuk Kepala Bidang (lihat bagian di atas).

\section{P e m bu a t an Ke put u s a d i Tingkat Dinas}

Sebelum tahun 2005

pembuatan keputusan di tingkat Dinas dipengaruhi oleh gaya kepemimpinan Kepala Dinas, terutama terlihat pada keputusankeputusan yang bersifat jangka pendek. Prosesnya bersifat bottom up, dimulai dari level Kepala Seksi. Setelah tahun 2005 pengambilan keputusan tentang halhal yang bersifat jangka panjang, berdimensi hukum dan keuangan, biasanya berlangsung secara hirarkis dan prosedural. Untuk pengambilan keputusan yang bersifat teknis kadang kala menyertakan staf untuk memberikan pertimbangan. Tapi lebih sering yang didengarkan adalah Kepala Bidang. Suara dari Kepala Seksi dan staff relatif tidak didengar.

\section{P e $m$ bu at an Ke put u s a ndi Tingkat Bidang}

Sebelum tahun 2005

pengambilan keputusan di tingkat Bidang biasanya lebih mengedepankan keinginan atasan, meskipun staf dan Kepala Seksi diajak-serta. Setelah tahun 2005 biasanya lebih mengedepankan pertimbangan yang rasional dengan melibatkan Kepala Seksi.

Kadangkala juga keputusan langsung sendiri oleh Kepala Bidang.

Kiranya pengambilan keputusan di level Dinas maupun Bidang sulit ditunjukkan perbedaannya antara sebelum dan setelah 2005. Sekalipun prosesnya mungkin bottom up, pada akhirnya toh keputusan diambil oleh karena memang menjadi tanggungjawab dari Kepala. Pendekatannya masih legal-formal: staff relatif tidak diikutkan dalam pengambilan keputusan, baik sebelum maupun setelah 2005. Boleh jadi inilah yang masih merupakan ciri birokrasi Indonesia pada umumnya: legal, formal, sangat prosedural, tidak fleksibel, tidak substansial.

\section{Proses Perencanaan}

Sebelum tahun 2005

perencanaan program dan kegiatan Dispertanak disusun mengacu kepada Rencana Strategis Pembangunan Pertanian Tahun 2006 - 2010. Rencana kerja tahunan Dinas disusun dari prioritas Dinas dan penyerapan aspirasi masyarakat. Ada pula yang didasarkan pada program nasional. 
Artinya penyusunan program dan kegiatan dilakukan kombinasi antara pola bottom up dan top down dan dilakukan oleh setiap Bidang. Karena itu kadang-kadang terjadi tumpang-tindih program antar Bidang.

Setelah tahun 2005 rencana

kerja anggaran disusun oleh Subbagian Perencanaan dan penyusunan program berdasarkan usulan dari setiap Bidang, sehingga tidak ada lagi tumpang tindih kegiatan antar bidang. Tetap ada percampuran antara aspirasi masyarakat, desain teknis Dinas dan program nasional.

Dibentuknya subbagian baru, yakni Subbagian Perencanaan, menjadikan program-program Dinas lebih terarah. Subbagian ini mengkoordinasikanmensinkronkan rencana antar bidang. Ini adalah sesuatu yang bagus. Tetapi, sebenarnya ketika subbagian ini belum terbentuk, fungsi koordinasi perencanaan mestinya tetap dijalankan oleh Kepala Dinas. Mengapa dia terkesan tidak melakukan fungsi ini, sehingga rencana pada periode sebelumnya saling tumpang-tindih antar bidang? Seharusnya tidak semua fungsi pimpinan ditampung dalam suatu struktur tersendiri. Fakta ini mengundang dua penafsiran: Kepala Dinas pemalas atau memang dia ingin menambah lebih banyak pegawai yang direkrutnya secara nepotis.

\section{Citra Dinas di Mata Masyarakat} Sebelum tahun 2005 citra Dinas sangat baik. Petani merasa bahwa dinas sangat membantu mereka, terutama dalam hal pemberian bantuan, sekalipun jumlah sangat kecil (lihat bagian "anggaran" di atas). Namun sebenarnya minat masyarakat terhadap sektor pertanian sangat rendah. Mereka lebih meminati sektor kehutanan atau menjadi TKI, mungkin juga karena memang pertanian tidak memperoleh perhatian yang memadai dari Pemkab (lihat "anggaran" di atas). Setelah tahun 2005 sebagian masyarakat di Kabupaten Nunukan sudah beralih profesi ke sektor pertanian dan perkebunan. Masyarakat semakin kritis dalam memberikan penilaian kepada Dinas. Adakalanya bantuan yang mereka terima dinilai tidak tepat, karena bukan yang mereka butuhkan atau tidak dapat dipakai. Demikian pula, dalam pengurusan perijinan terkadang dinas dianggap mempersulit.

Ta m p a k y a m a s y a r a k t Nunukan, sebagaimana masyarakat Kalimantan pada umumnya, tidak terbiasa bertani. Kebiasaan mereka adalah merambah hutan, memetik hasil tanpa menanam. Bertani adalah pekerjaan yang serius, butuh kesabaran dan hasilnya belum tentu sesuai dengan keinginan kita. Tapi hasil pertanian tampaknya semakin menunjukkan keuntungan yang lumayan, sehingga sebagian masyarakat sudah meminati sektor ini. Karena itu Dinas perlu memperbaiki pelayanannya kepada masyarakat. Momentum ini harus dimanfaatkan sebaik-baiknya. Jumlah anggaran untuk pengembangan pertanian perlu dinaikkan, kalau memang sektor ini 
dinilai lebih realistis untuk

memakmurkan warga Nunukan.

\section{Evaluasi Internal}

Sebelum tahun 2005 dibuat laporan mingguan, bulanan, semester dan tahunan. Tapi evaluasi internal kurang berjalan. Setiap Bidang sibuk dengan pekerjaan masing-masing. Setelah tahun 2005 dibuat laporan bulanan kepada Bappeda sebagai bahan untuk laporan semester dan nantinya laporan kinerja instansi pemerintah (LAKIP). Evaluasi internal relatif lebih baik dan makin ditegaskan. Evaluasi kiranya perlu dilakukan secara lebih serius. Dengan mengevaluasi apa yang sudah kita kerjakan selama setahun yang lalu atau bahkan lima-sepuluh tahun yang lalu, kita dapat mengetahui apa yang kurang dan salah yang sudah kita kerjakan. Berdasar itu kita memperbaiki diri. Jika ini dilakukan benar-benar, maka perbaikan dan kemajuan akan terlihat dalam waktu yang tidak terlalu lama. Mestinya visi Indonesia 2025 dibangun melalui kegiatan evaluasi dan perbaikan terus-menerus, di samping memupuk mimpi dan semangat kemajuan di masa depan.

\section{Pengawasan Eksternal}

Sebelum tahun 2005

pengawasan yang dilaksanakan oleh Inspektorat, BPKP dan BPK lebih dominan dibanding DPRD dan masyarakat. Pengawasan oleh Inspektorat relatif lebih lemah dan kurang tegas dibanding BPKP atau BPK. Setelah tahun 2005 DPRD dan masyarakat yang diwakili oleh
LSM sudah sangat aktif dalam melaksanakan pengawasan terhadap Dinas. Saat ini pengawasan yang dilakukan adalah sebagai berikut:

a. Pengawasan oleh Inspektorat Pengawasan oleh Inspektorat Kabupaten selama ini dilakukan masih bersifat pembinaan. Jika didapati kesalahan administrasi pada pelaksanaan kegiatan, Inspektorat melakukan teguran, tetapi jika kesalahan dianggap fatal dan merugikan keuangan negara, dilakukan upaya pengembalian keuangan negara. Selama ini Inspektorat selalu memberikan Laporan Hasil Pemeriksaan, tetapi biasanya dapat diselesaikan, baik berupa teguran, pengembalian keuangan negara maupun sanksi administrasi.

b. Pengawasan oleh BPKP Pengawasan oleh Badan Pemeriksa Keuangan dan Pembangunan lebih bersifat pembinaan perencanaan. Sesuai dengan Kesepakatan Bersama antara Pemerintah Kalimantan Timur dengan BPKP, badan ini melakukan supervisi terhadap perencanaan pembangunan, keuangan, kinerja dan administrasi. Selama ini BPKP membantu Dispertanak dalam penyusunan Renstra, Lakip dan perbaikan administrasi.

c. Pengawasan oleh BPK Pengawasan oleh Badan Pemeriksa Keuangan lebih bersifat analitis, jika didapati kesalahan yang dianggap 
penting, dilakukan pemeriksaan investigatif. Selama ini Dispertanak belum pernah mendapat teguran yang bersifat kesalahan prosedural maupun keuangan dari BPK.

\section{d. Pengawasan oleh DPRD}

Pengawasan oleh DPRD saat ini lebih pada penggunaan anggaran dan efektifitas kegiatan ditinjau dari pencapaian program. Pengawasan DPRD biasanya dilakukan dengan melakukan Rapat Dengar Pendapat (RDP) dan Rapat Konsultasi. Sejak tahun 2006, Dispertanak baru dipanggil 2 kali dalam RDP.

e. Pengawasan oleh masyarakat Pengawasan oleh masyarakat biasanya tercermin dari penilaian lewat media massa maupun laporan oleh LSM, ataupun secara insidental berupa keluhan oleh masyarakat terhadap suatu kegiatan Dinas. Biasanya penilaian lewat media massa lebih efektif karena langsung mendapat tanggapan. Dispertanak beberapa kali diberitakan melakukan kesalahan dalam pelaksanaan kegiatan di lapangan, tetapi umumnya terjadi karena miskomunikasi dan kesalahpahaman, sehingga lebih mudah diselesaikan.

$$
\text { Paparan di atas }
$$

menunjukkan, pengawasan sudah cukup memadai. Perlu dicari, apa yang keliru dari sistem pengawasan kita, sehingga birokrasi masih terkesan lambat, tidak efektif dan boros. Mestinya pengawasan berfungsi untuk mencegah dan mengobati semua karakter buruk birokrasi ini. Kemungkinannya: pengawasan kurang galak, kurang efektif, atau memang mereka yang mengawasi dapat diajak kompromi oleh birokrasi.

\section{Efektivitas}

Sebelum tahun 2005, pelaksanaan kegiatan belum efektif karena lingkup kerja yang luas dan belum adanya pembagian tupoksi yang jelas setiap bidang dan seksi. Setelah tahun 2005 pelaksanaan kegiatan relatif lebih efektif, karena setiap Bidang dan Seksi sudah diatur tugas pokok dan fungsinya secara jelas. Hanya saja kadangkadang ada program atau kegiatan yang tidak berguna bagi masyarakat, tidak tepat sasaran.

Dalam kebiasaan birokrasi kita, mengukur efektivitas adalah dengan cara membandingkan realisasi atau pelaksanaan dengan target atau rencana. Cara ini agak menyesatkan, karena target itu sendiri belum tentu pantas target biasanya rendah, sehingga mudah dicapai dan di akhir tahun akan dapat dinilai sangat efektif. Menilai efektivitas yang lebih tepat adalah dengan menilai kegunaannya bagi masyarakat. Disebutkannya oleh informan, bahwa kadang ada program atau kegiatan yang tidak berguna dan tidak tepat sasaran, kiranya mengindikasikan belum bersungguh-sungguh birokrasi kita bekerja dengan orientasi pada kinerja. Orientasi kita masih pada penghabisan anggaran, tidak peduli 
terhadap manfaat dari kegiatan ini. ini kiranya merupakan kemubadziran, inefisiensi dan harus dicarikan upaya pemecahannya.

\section{Efisiensi}

Sebelum tahun 2005 pelaksanaan kegiatan sangat efisien, karena anggaran dan personil terbatas tapi beban kerja yang berat. Setelah 2005 malah kurang efisien. Setiap bidang punya program yang sering tumpang-tindih, meskipun sudah ada Subbagian Perencanaan.

Seperti telah disinggung dalam bagian "jumlah pegawai" di atas, semula Dispertanak memiliki banyak beban kerja dan sedikit pegawai. Sementara itu setelah 2005 beban kerjanya berkurang, sedangkan pegawainya bertambah banyak. Dengan asumsi beban kerja itu sama-sama tercapai, maka berarti pada kurun waktu sebelum 2005 lebih efisien daripada sesudahnya. Mungkin ini fenomena yang relatif manusia: dalam kondisi serba terbatas, orang cenderung lebih giat bekerja daripada ketika dia berada dalam situasi yang longgar. Karena harusnya perlu dicari jumlah pegawai dan anggaran yang paling pas untuk volume kerja tertentu.

\section{Proses Inovasi}

Sebelum tahun 2005, inovasi tidak mudah dilakukan oleh organisasi pemerintah, karena belum adanya Perda tentang tupoksi Dispertanak. Setelah tahun 2005 dengan sarana dan prasarana yang memadai dan ditunjang dengan adanya sumber daya manusia yang memadai Dispertanak telah melakukan inovasi khususnya dalam melaksanakan program dan kegiatan, sehingga tahun ini Bupati Nunukan dianugerahi penghargaan oleh Bapak presiden SBY sebagai salah satu daerah yang dapat meningkatkan produksi pangan khususnya beras. Tapi secara umum Nunukan relatif ketinggalan dibandingkan daerah lain, karena letaknya yang jauh dari ibukota pemerintahan.

Kiranya masih sangat sedikit inovasi yang dilakukan oleh Dinas. Prestasi "dapat meningkatkan produksi beras" agak sulit disebut inovasi, meskipun memang adalah sebuah prestasi -tapi seberapa tinggi? Apakah prestasi itu sudah sewajarnya atau jauh melampaui potensinya? Dalam kaitan ini kiranya birokrasi perlu dibebaskan dari budaya proyek, budaya formalisme dan budaya sekedar bekerja apa adanya, sekedar untuk mengesahkan gaji yang telah diterimanya. Perlu diciptakan prosedur dan mekanisme tertentu yang mendorong berkembang dan dijalankannya kreativitas dan inovasi dari pegawai-pegawai secara individual. Apa yang disebut sebagai learning organisation -di mana pegawai dan organisasi diberi ruang untuk berkesperimen, melakukan kesalahan, dan bekerja memperbaiki kesalahan itu untuk berprestasi lebih tinggi (lihat Elu/Purwanto 2011: 12.1-36, juga Wibawa 2005: 10, 90)-- perlu dikembangkan terus-menerus.

\section{PENUTUP}

Deskripsi tentang perubahan di dalam Dispertanak di atas dapat 
dirangkum ke dalam tabel di bawah ini. Terlihat bahwa dari 19 aspek yang terinci menjadi 30 butir penilaian terdapat 13 (42\%) butir yang mengalami perubahan positif, $5(16 \%)$ negatif dan $12(39 \%)$ tetap. Bahwa perubahan positifnya kurang dari separo, ini kiranya tidaklah menggembirakan. Dispertanak perlu melakukan mawas diri, untuk kemudian membulatkan tekad melakukan perubahan-perubahan positif yang signifikan.

Tabel 3. Perubahan Berbagai Aspek Organisasi Dispertanak Kabupaten Nunukan Sebelum dan Setelah Tahun 2005

\begin{tabular}{|c|c|c|c|}
\hline No. & Aspek organisasi & Perubahan & Nilai *) \\
\hline 1. & Peralatan kantor & Semakin banyak, semakin bagus & + \\
\hline \multirow[t]{5}{*}{2.} & Struktur organisasi & & \\
\hline & a. Bagan & $\begin{array}{l}\text { Sedikit lebih ramping, karena tugas dan } \\
\text { wewenang juga berkurang }\end{array}$ & + \\
\hline & b. Jumlah pegawai & $\begin{array}{l}\text { Malah berlipat-ganda, padahal tugas dan } \\
\text { wewenang berkurang }\end{array}$ & - \\
\hline & c. Aliran tugas & Tidak ada perubahan: hierarkhis & o \\
\hline & d. Komunikasi formal & $\begin{array}{l}\text { Lebih sering, karena peralatan kantor } \\
\text { lebih baik }\end{array}$ & + \\
\hline 3. & Komunikasi informal & $\begin{array}{l}\text { Berubah lewat HP dan internet, di } \\
\text { samping tatap-muka }\end{array}$ & + \\
\hline 4. & Budaya organisasi & $\begin{array}{l}\text { - Keterbukaan antar bidang menurun } \\
\text { - Nepotisme tidak berkurang } \\
\text { - Isteri pejabat tetap sering ikut } \\
\quad \text { campur }\end{array}$ & - \\
\hline \multirow[t]{2}{*}{5.} & $\begin{array}{l}\text { Kualitas dan motivasi kerja } \\
\text { pegawai }\end{array}$ & - Kualitas meningkat & + \\
\hline & & $\begin{array}{l}\text { - Motivasi menurun, karena beban } \\
\text { kerja per pegawai menurun }\end{array}$ & - \\
\hline \multirow[t]{2}{*}{6.} & Anggaran & - Jumlahnya sedikit meningkat & + \\
\hline & & $\begin{array}{l}\text { - Penggunaannya masih berorientasi } \\
\text { proyek }\end{array}$ & o \\
\hline 7. & Dukungan bupati & Sangat kurang, tidak berubah & - \\
\hline 8. & Visi organisasi & $\begin{array}{l}\text { - Lebih sederhana } \\
\text { - Tetap hanya lips service, formalitas }\end{array}$ & o \\
\hline \multirow[t]{2}{*}{9.} & Kepemimpinan kepala dinas & $\begin{array}{r}\text { - Berubah dari berorientasi pada } \\
\text { manusia menjadi pada tugas }\end{array}$ & + \\
\hline & & - Menjadi lebih individualis & o \\
\hline 10. & Kepemimpinan kepala bidang & Mirip dengan perubahan di atas & $+/ \mathrm{o}$ \\
\hline
\end{tabular}




\begin{tabular}{|c|c|c|c|}
\hline 11. & $\begin{array}{l}\text { Pembuatan keputusan di } \\
\text { tingkat dinas }\end{array}$ & $\begin{array}{l}\text { Tidak berubah: hanya melibatkan kepala } \\
\text { bidang, kurang partisipatif }\end{array}$ & o \\
\hline \multirow[t]{2}{*}{12.} & $\begin{array}{l}\text { Pembuatan keputusan di } \\
\text { tingkat bidang }\end{array}$ & - Lebih rasional & + \\
\hline & & - Tetap kurang partisipatif & 0 \\
\hline \multirow[t]{2}{*}{13.} & Proses perencanaan & $\begin{array}{c}\text { - Lebih sinkron antar -bidang, karena } \\
\text { dibuat Subbagian Perencanaan }\end{array}$ & + \\
\hline & & $\begin{array}{l}\text { - Tetap campuran top-down dan } \\
\text { bottom-up }\end{array}$ & o \\
\hline 14. & Citra dinas & $\begin{array}{l}\text { Relatif tidak berubah, tapi masyarakat } \\
\text { semakin kritis }\end{array}$ & o \\
\hline 15. & Evaluasi internal & $\begin{array}{l}\text { Sedikit lebih baik, laporan bulanan ke } \\
\text { Bappeda untuk nanti dibuat LAKIP }\end{array}$ & + \\
\hline \multirow[t]{2}{*}{16.} & Pengawasan eksternal & $\begin{array}{l}\text { - DPRD dan masyarakat menjadi lebih } \\
\text { aktif mengawasi }\end{array}$ & + \\
\hline & & - Tetap kurang efektif & 0 \\
\hline \multirow[t]{2}{*}{17.} & Efektivitas & - Relatif lebih efektif & + \\
\hline & & $\begin{array}{l}\text { - Tetap ada program yang tidak } \\
\text { berguna bagi masyarakat }\end{array}$ & o \\
\hline 18. & Efisiensi & $\begin{array}{l}\text { Lebih boros, karena pekerjaan menurun } \\
\text { tapi jumlah pegawai semakin banyak }\end{array}$ & - \\
\hline 19. & Proses inovasi & Belum ada & 0 \\
\hline
\end{tabular}

*) Keterangan: + : membaik, - : memburuk, o = tetap

Selanjutnya, berdasarkan komentar-komentar yang diajukan oleh penulis terhadap setiap aspek di atas dapat digarisbawahi faktor-faktor penghambat perubahan dan diringkaskan saran-saran untuk berbagai pihak terkait sebagai berikut. Faktor-faktor penghambat perubahan berbeda-beda dari satu aspek perubahan ke aspek lain. Namun dapat dirangkum sebagai berikut:

1. M a s i c u k u pdominann y a nepotisme dalam kepegawaian.

2. Orientasi terhadap penghasilan masih cukup tinggi, mengalahkan orientasi terhadap pelayanan.

3. Ketergantungan pada karakter pimpinan, belum terciptanya sistem perilaku.

4. Masih berlangsung pencampuran tugas dinas dan urusan pribadi.

5. Dukungan, desakan, dorongan dan pengawasan dari instansi di luar dinas masih kurang.

6. Kurangnya pengkondisian untuk proses partisipasi, termasuk transparansi pengambilan keputusan.

P e n y e b u t a n f a k t or- fakt or penentu di atas dapat dengan mudah menuntun kepada pemikiran tentang perlunya beberapa hal yang harus dilakukan untuk melakukan perbaikan. Sekalipun demikian, mengakhiri tulisan ini, tetap perlu disajikan di sini saran-saran praktis untuk Dispertanak pada khususnya dan Pemkab Nunukan s e r t a K a li m a n t a n Ti m u r p a d a umumnya sebagai berikut. Secara implisit dalam daftar ini telah tersirat pula topik-topik kajian tentang birokrasi pemerintah yang perlu atau dapat dilakukan oleh para ilmuwan administrasi negara: 
1. Hendaknya kemajuan teknologi yang telah diadopsi oleh Dinas dimanfaatkan sebaik-baiknya untuk pengolahan data, merencanakan program dan melakukan komunikasi serta koordinasi intern dan ekstern antar instansi, di dalam maupun di luar Nunukan.

2. Jumlah pegawai perlu dikurangi, disesuaikan dengan beban kerja Dinas yang juga berkurang.

3. Keakraban dan kebersamaan di antara pegawai Dinas perlu dipupuk kembali. Perhatian pimpinan terhadap pegawai dan tugas perlu diseimbangkan atau diserasikan dengan melihat situasi dan kondisi yang ada.

4. Nepotisme harus secara serius dihapus.

5. Para pejabat perlu betul-betul diarahkan untuk menggunakan anggaran benar-benar untuk kesejahteraan rakyat, dengan evaluasi yang serius setiap tahun.

6. Anggaran untuk bidang pertanian perlu ditingkatkan, proporsional dengan sumbangan PDRBnya.

7. Visi Dinas dan Kabupaten perlu dirumuskan secara lebih serius, dan realisasinya perlu dievaluasi secara serius pula.

8. Dalam pengambilan keputusan, sekalipun hal ini adalah wewenang pimpinan, para pegawai perlu juga dilibatkan agar supaya pelaksanaannya dapat berjalan lebih lancar.

9. Kondisi di mana masyarakat semakin melek

k e w a rga n e g a r a a n n y a p e r l u direspon dengan membuka pintu partisipasi selebar-lebarnya, baik pada tahap perencanaan, pelaksanaan dan evaluasi programprogram Dinas.

10. Pengawasan eksternal perlu diefektifkan, sehingga kebocoran dana negara dapat dikurangi dan dicegah.

11. Model learning organisation perlu diterapkan di dalam Dinas: program direncanakan secara inovatif dan serius, dilaksanakan secara serius, lalu dievaluasi secara sistematis dan kesalahan/ kekeliruan sebagai risiko dari inovasi diterima sebagai bahan pelajaran, tidak untuk diberi sangsi oleh atasan.

\section{DAFTAR PUSTAKA}

Andari, Eni. (2005). Meraih Keunggulan Melalui Pengintegrasian Perencanaan Sumber Daya Manusia dan Perencanaan Strategik dalam Jurnal Siasat Bisnis, Edisi Khusus On Human Resources.

BPS Nunukan,. (2011). Kabupaten Nunukan dalam Angka 2010

Dujo, Djaiz, "Pengaruh Penerapan

Sistem Administrasi Partisipatif terhadap Pelaksanaan Pengajaran dalam Lingkungan Sekolah Lanjutan di Kotamadya dan Kabupaten Gorontalo ", artikel tanpa tahun, dalam http://abstrak.digilib.upi.edu/ 
Samodra Wibawa

Direktori/DISERTASI/ADM INISTRASI_PENDIDIKAN /Djaiz_Dujo_Pengaruh_Pen erapan_Sistem_Administrasi _Partisipatif.pdf, diakses 5 Desember 2011

Kahar, Irawaty A. (2008). Konsep

Kepemimpinan dalam Perubahan Organisasi (Organizational Change) pada Perpustakaan Perguruan Tinggi dalam Pustaha: Jurnal Studi Perpustakaan dan Informasi, Vol.4, No.1

Elu, Wilfridus B. dan Agus Joko Purwanto. (2011). Inovasi dan Perubahan Organisasi, Jakarta: UT

Prawirodirdjo, Arto Suharto. (2007). Analisis Pengarus Perubahan Organisasi dan
Budaya Organisasi terhadap Kepuasan dan Kinerja Pegawai Kantor Direktorat Je nd e r a l P a jak, Te s is Magister Manajemen UNDIP, Semarang

R obbin s, S t e p he n P. ( 2003 ). Organizational Behavior, New Jersey: Prentice Hall

Wibawa, Samodra. (2005). Peluang Penerapan New Public Management untuk Kabupaten di Indonesia, Jogja: Gadjah Mada University Press

Yuwono, C.D. Ino dan M.G. Bagus Ani Putra. (2005). Faktor Emosi dalam Proses Perubahan Organisasi dalam Jurnal INSAN Vol. 7 No. 3

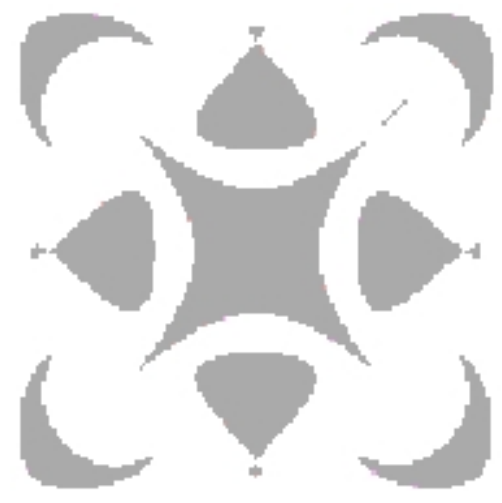

